\title{
Shaft Power Estimation in Induction Motor Operating under Unbalanced and Harmonics Voltages
}

Sousa Santos, Vladimir; Viego, Percy Rafael; Gómez, Julio Rafael; Quispe, Enrique Ciro; Balbis Morejon, Milen

\begin{abstract}
In this work the application of a method to estimate the shaft power of induction motors operating in the presences of unbalanced and harmonics voltages is presented. The method uses the steady state equivalent circuits, with some considerations for the analysis of motor performance, fed with unbalanced and harmonic voltages. The parameters of circuits are determined with low invasiveness, by applying a Bacterial Foraging Algorithm as technique of evolutionary search. With this, the shaft power can be estimated at any operating point. The method was tested in a $12.6 \mathrm{~kW}$ motor working in an industrial power supply grid, with harmonics and unbalanced voltage.
\end{abstract}

\section{Keywords}

Equivalent circuits, harmonic analysis, induction motors, industrial power systems, power quality, parameter estimation, unbalanced voltage. 